\title{
Research on Hainan's Global Tourism Development Strategy Based on SWOT Analysis
}

\author{
Shuyu Zhang, Hailan Hong \\ Hainan University, Danzhou, Hainan, 571737, China
}

\begin{abstract}
Promoting global tourism is the re-positioning of China's tourism development strategy at a new stage and it is a change with far-reaching significance. In this paper, from the perspective of global tourism development and SWOT analysis, this paper makes a comprehensive analysis of the advantages, disadvantages, opportunities and threats of Hainan tourism development, in order to provide useful inspiration for the development of a scientific and effective model of global tourism development in Hainan Province.

Keywords: Hainan province; global tourism; SWOT analysis; point line surface
\end{abstract}

\section{The background and theoretical summary of the global tourism thought}

In order to thoroughly implement the instructions of Premier Li Keqiang "play tourism in expanding domestic demand, steady growth, employment, poverty alleviation, the unique role of the people", the National Tourism Administration issued on the "national tourism demonstration area" announcement of. It is not only the path of transformation and upgrading of regional tourism and upgrading of quality and efficiency, but also the new concept and model of leading and coordinating the coordinated development of regional national economy and society.

In the primary stage of tourism development in China, mainly to build scenic spots, scenic spots, hotels, guesthouses. However, the development of tourism to 
the present, has reached the national tourism and individual travel, traveling by car-based new stage, the traditional tourist attractions can not meet the modern tourism development needs. In the "tourist attractions" mode, the construction of closed scenic spots, business and society is fragmented, isolated, and some even conflict, resulting in scenic spots inside and outside the "double heaven", and "global tourism" is to change this pattern. "Global tourism" is the panoramic view of the system of tourism space is out of the traditional tourism planning modern tourism, tourism planning out of small tourism. Therefore, China should change the mode of tourism development, innovation of tourism development strategy, and promote China's tourism from the "tourist attractions" to "global tourism" change.

At the beginning of 2016, the National Tourism Administration of China carried out the first batch of global tourism demonstration area to create the work, of which Hainan Province was identified as the first global tourism to create the province, the purpose is to Hainan Province, the tourism industry as the dominant industry, through the economic and social resources in Hainan Province Especially the tourism resources, related industries, ecological environment, public services, institutional mechanisms, policies and regulations, and the quality of civilization and so on to carry out all-round and systematic optimization and upgrading, to achieve regional organic integration of resources, industrial integration development, social sharing, Industry to promote and promote the coordinated development of economic and social Hainan, Hainan Province, a tourism-related elements of a comprehensive configuration to fully meet the needs of tourists experience a comprehensive tourism destination, open tourism destination.

\section{The status of global tourism development of Hainan Province}

In recent years, Hainan Province has continued to accelerate the pace of international tourism island construction, deepen the reform of tourism management system, accelerate the construction of key tourism projects, develop rural tourism market, build and enhance new tourism products such as duty-free shopping, cruise yachts, wedding tourism, Tourist market development and tourism promotion, improve the quality of tourism services, Hainan tourism market achieved rapid development, the number of tourists and tourism revenue to maintain double-digit growth.

In 2016 the Boao Forum for Asia Global Tourism and Media Summit on the Chinese Academy of Social Sciences, deputy director of the Center for Tourism Research Dai Xuefeng proposed that Hainan in the global tourism, not only by the national attention, and the Hainan Provincial Tourism Commission has done a lot of work, Hainan Tourism has achieved very good results. In 2015, Hainan Province received 53,356,600 tourists trips, an increase of $11.4 \%$; to achieve total tourism revenue $57,249,000,000$ yuan, an increase of $13 \%$, the province's tourism 
accounted for $7.6 \%$ of GDP. In the case of slowing economic growth in various industries, the province's overall tourism economy maintained stable and rapid development trend for the province's economic growth has made due contributions to the status of tourism in Hainan, more and more important.

However, in recent years, the added value of tourism in Hainan increased year by year, accounting for the proportion of GDP gradually increased, but with some large domestic tourism compared to Hainan Province, tourism added value is relatively low; and tourism as a pillar industry in some countries and regions, Tourism added value accounted for the proportion of GDP is low, the tourism market development is not strong driving force for economic growth. Therefore, the need to further promote tourism resources in Hainan Province, institutional mechanisms and other aspects of innovation, laying the foundation for the development of global tourism in Hainan, the whole of Hainan tourism to become a consensus.

\section{SWOT analysis of global tourism in Hainan Province}

SWOT analysis also known as the situation analysis. S, W, O, T respectively represent: Strength, Weakness, Opportunity, Threat.

On the whole, SWOT can be divided into two parts: Part $1 \mathrm{~S}, \mathrm{~W}$, the main analysis of internal conditions; Part $2 \mathrm{O}, \mathrm{T}$, the main analysis of external conditions. Use of this method can be found from their own benefit, and worthy of the factors, as well as their own disadvantage, to avoid the factors found problems, find a solution to develop development plans.

The basic idea of making plans: to take advantage of factors to overcome the disadvantages of factors, the use of opportunity factors to resolve the threat factors. In other words, is to sum up the past, based on the present, focus on the future. The advantage of SWOT analysis is that it can make a comprehensive, systematic and accurate research on the situation of the research object, so as to formulate the corresponding development strategy, plan and countermeasure according to the research result.

\subsection{Advantage analysis (Strength)}

Traffic location advantages. Hainan is located in the southernmost part of China, is China's second largest island, backed by the mainland, near Hong Kong and Macao, South Southeast Asian countries of the special geographical location of Hainan is China and the world an important gateway. The province formed a highway as the main artery, "three vertical and four horizontal" as the main frame of the road traffic. Shipping is also the focus of the province's traffic, the province's total of 54 ports, the main port berths 60, routes can reach Russia, Japan, Korea, Southeast Asian countries, Africa, Europe and countries. Hainan has Haikou Meilan and Sanya Phoenix two large international airport, has opened 384 domestic routes, of which 21 international routes, as the first choice of the island, the most convenient means of transport. 
Tourism resources advantages. Hainan Island coastline of up to $1528 \mathrm{~km}$, most of the coastal coastal areas calm, clear water, sea water temperature is generally $18{ }^{\circ} \mathrm{C} \sim 30{ }^{\circ} \mathrm{C}$, sunny and bright. There are more than 300 tourist hotels and resorts in the whole city, including 5A, 5, 4A, 9, and other A-level scenic spots in the city, coastal, hot spring and mountainous areas. The province is extremely rich in tropical biological resources and there are 8 state-level nature reserves, the provincial nature reserve 23, with a total area of 280 million hectares. Hainan Province also has a certain ethnic customs resources, Li, Miao, Hui, Zhuang and other 37 ethnic minorities, due to historical and cultural relations of origin, the central mountainous region of the Li Miao still retains many simple and honest folk customs and life Habits, so that the social characteristics of Hainan is unique and has its unique tourist value.

Ecological environment advantages. Hainan is a tropical monsoon climate, fresh air, sunny, evergreen vegetation, long summer without winter, the central region of the central air temperature is low, the southwest is high, the average temperature of $17.2{ }^{\circ} \mathrm{C}$ in July, the average temperature of $28.4{ }^{\circ} \mathrm{C}$, average annual sunshine 300 days or more. Hainan's unique climate conditions, making the province in China's tourism market occupies a great advantage, and now, "summer to Hainan to summer" and "winter to Hainan to play in the water" as the majority of tourists agree with the tourist slogan. Hainan is also known as "natural greenhouses", "tropical orchards" and "tropical gardens". It is rich in tropical crops and tropical fruits, while 68 natural harbors dot the ocean. In addition, Hainan is a rare uncontaminated pure land, known as the "no pollution of the longevity island", the province's overall environmental quality in the national leading level, the environmental quality index remained within a level.

Huge source market. At present, Hong Kong, Macao and overseas Chinese is the province more stable inbound tourism market, while the province's domestic market is still the traditional and basic source of tourists, Hainan tourism market is the foundation and mainstream. At the same time, in recent years due to the construction and development of tourism in Hainan Province, making foreign tourists market has a faster development. Now, the domestic residents to Hong Kong, Macao and Taiwan tourism growing demand, Hainan tourism as an extension of these tourist destinations, its market prospects are promising, development potential is a tourist tourist market, a new growth point.

\subsection{Weakness analysis (Weakness)}

The city system seems to loose sand. As the geographical conditions of Hainan, Hainan cities can now be described as fragmented, little contact, the basic provincial situation, "First, the number of scale and development space between the prominent contradictions, such as the high number, resulting in each city and county government The management area is relatively small; the population is too small, the structure is unbalanced, the strength is weak, the economic aggregate is relatively low. Second, the contradiction between the structure and resource allocation, such as a large number of development resources such as highways, Rail, airports, industrial facilities, etc. set in the coastal cities and 
counties around the island, it is difficult to service to the central inland cities and counties, but Hainan is currently difficult to balance the strength of incompetence, leading to coastal cities and counties and inland cities and counties in resources Distribution has produced a serious contradiction. " This urban development structure not only does not meet the global tourism will be the province as a big city planning, the formation of a super city as the center of the mega-city group and satellite city construction concept, and is bound to become a global tourism process on the road to a stumbling block.

The local economy is underdeveloped. According to the data show that in 2015 the 31 provinces (excluding Hong Kong, Macao and Taiwan) released economic data (GDP), the total GDP of Hainan Province 3702.8 billion yuan, ranked No. 28, and ranked first Of the Guangdong Province (7.28 trillion yuan) difference between the poor. Low level of urbanization, resulting in local economic support from the tourism industry will be relatively small, the tourism industry can provide the basic services will be stretched, the resources are insufficient to cope with the development of tourism, and there is no demand for a strong local market, To a certain extent, just reflects the status of the cities and counties in Hainan Province, a scattered sand - in addition to Sanya, Haikou and other cities compared to the relatively prosperous, other cities and rural construction are relatively backward, can not form a whole image of Hainan.

Tourism as a pillar industry of direct benefits has not yet emerged. Hainan tourism reception number and income increased year by year, but the total income is not large, the tourism industry as a pillar industry in the proportion of the province's total economy is relatively small, the tourism industry is still a number of rather than efficiency, tourism management is Extensive rather than quality. At the same time, regional development is not balanced, tourism enterprises and tourist attractions are mainly concentrated in the eastern coastal and Haikou, Sanya and other cities and counties, western, central tourism development is slow, the local economy multiplier effect is small, industry leading role is not obvious. A considerable number of tourism enterprises economic foundation is weak, heavy debt, lack of liquidity, market competitiveness is weak, poor ability to resist risks.

\subsection{Opportunity analysis (Opportunity)}

The improvement of living standards and changes in consumer attitudes. With China's per capita income and personal disposable income increases, as well as the continuous improvement of living standards. Residents of the consumption concept is also constantly changing, more and more focus on the "spiritual life" of the pursuit and enjoyment, tourism, overall consumer demand. According to statistics, the past 10 years, the number of Chinese tourists increased steadily, tourism consumption gradually increased. The average annual growth rate of more than $10 \%$ of the total annual growth rate of tourism consumption is also more than $10 \%$, higher than the GDP growth rate. Hainan residents around the city of short-distance travel and other provinces to Hainan to sightseeing, business, conferences, study tours and other tourist activities will further increase. 
Hainan Province, known as "longevity island," said the experts believe that the longevity of Hainan is the secret of Hainan Island has a beautiful pure ecological environment. As the only tropical island resort in China, Hainan Island has a great attraction and competitiveness with the brand of "

"Along the way", dream of Hainan. "Along the way," is the Silk Road economic belt and the 21 st century sea Silk Road short. In terms of history, or from the reality, Hainan will be one of the essential part. Hainan is the gateway to the two continents (Asia, Oceania) and the "two oceans" (the Pacific Ocean and the Indian Ocean) and the "crossroads" to the "two continents" (Southeast Asia and Northeast Asia). First of all, as the Asia-Pacific region and the world's most important maritime transport one of the South China Sea annually through the ship as many as 100,000 , China's $3 / 4$ of exports of goods, global $1 / 3$ of international trade, South China Sea route. Secondly, the abundance of Hainan products can be processed on the basis of the product, at the same time with various products in Southeast Asia match. Finally, there are many overseas Chinese overseas Chinese Hainan can continue this tradition, coordination of China and Southeast Asian countries in the cultural exchanges. These have decided to Hainan as a key node in the maritime Silk Road.

"International tourism island" strategic opportunities. January 4, 2010, the State Council issued the "State Council on the construction of international tourism in Hainan Island, the development of a number of opinions." The construction of international tourist island of Hainan, to build internationally competitive tourist destination, Hainan is to accelerate the development of global tourism, to achieve sound and rapid economic and social development of the major initiatives. Now has been completed food, clothing, housing, transportation, education, music, purchase a complete range of holiday and tourist reception facilities, and the corresponding service personnel, with the annual reception capacity of 30 million passengers. Hilton, Holidays, Crowne Plaza, Sofitel, Pullman, Kempinski, and so on, now has more than 70 four-star hotels in Hainan Island, such as Sheraton, Marriott, Ritz-Carlton, Hilton, Star, five-star hotel, Hainan Island, domestic and foreign tourists hailed as healthy islands, ecological islands, security islands, holiday islands.

Hainan tournament exhibition. Hainan 's events and exhibition through the continuous development of gradually formed a certain scale, brand - name effect is increasingly apparent, event tourism and MICE tourism more dynamic, will become a major driving force to promote tourism in Hainan Island. Important events in Hainan Island are: Hainan Island International Road cycling race, Danzhou International Marathon Cycling, Central Hainan Island International Grand Prix, Miss World, Mr. World, Snooker Haikou World Open and so on. With the variety of international events held in Hainan and exhibition capabilities to enhance the various events and exhibitions of international influence is also increasing, which will lead to tourism consumption, Hainan tourism opportunities for the strong development of the whole. 


\subsection{Threat analysis (Threat)}

Regional competition. The development of tourism industry in Hainan Province is facing the challenge of "North-South attack". Zhejiang, Guangdong and Hong Kong SAR are all developed areas of tourism in China. Its excellent service level, perfect urban construction and tourism management system constitute a strong force in Hainan Province. At the same time, the tourism market in Southeast Asia has a better visibility and reputation, the development of tourism in Hainan Province constitutes a strong domestic market for the source of competition. In 2001, the growth rate of foreign tourists in the double-digit cities and 20 provinces and cities, six provinces increased by $20 \%$ or more, indicating that the tourism industry in Hainan Province, domestic and international competition is fierce, to survive in such a market Is not easy.

Shortage of human resources. Along with the knowledge economy and the development of high-tech industry, the position and role of human resources in various factors of production are becoming more and more important. Hainan has been a relative shortage of human resources, and the continued lack of local development as a major resistance. For example: the province's more than 7000 tour guides, foreign language guide only 599 people, less than one-tenth.

The tourism industry lacks strong support. Due to historical and geographical reasons, the region has a weak economic base, a single industrial development pattern, fragmented administrative management, scattered information resources, and has not yet formed a "big tourism" pattern. The first and second industry support for the tertiary industry is not enough. In addition, tourism development caused by rising prices, while the low level of income, so that local residents do not support the development of tourism attitudes.

\section{The global tourism development countermeasure in Hainan province}

In 2016 the National Tourism Working Conference governor Liu Cigui on the global tourism were discussed, he suggested that "we want to Hainan Island as a big scenic area to planning and construction, to achieve 'sun and the moon with the stars", the province Is the beauty. "' Sun and Moon Tonghui "is the Hainan in the" multi-regulation "reform to promote the" Hai Cheng Wen, "' Sanya "regional integration, to create the leading radiation tourism development in the province; ", Is the first to create 100 characteristics of industrial town, 1000 beautiful villages, so that the beautiful villages and towns should become livable attractions, throughout the province. "Sun and Moon Tonghui stars" is equivalent to a large "global tourism" concept and support.

Promote global tourism, the key in the "global" word on the word, is from the point, line, surface all-round start on the urban and rural areas, scenic spots, transportation networks and other comprehensive construction, transformation, upgrading, so that all parts of the province Become livable, should travel, should 
be the tourism industry, tourism city, tourism village. Hainan to carry out global tourism pilot work need to start from the following aspects:

\subsection{Cross-Vertical and horizontal and through the world}

In the "line" of the building, first of all, to improve the accessibility of the "connection" function, the construction of the province's tourist traffic network, so that between the point and the smooth accessibility, little by little, to achieve the province's tourism barrier-free, , Tourist attractions, tourist towns and rural tourism between the accessibility to meet the travel needs of tourists. At present, Hainan Province, the mileage of $17,000 \mathrm{~km}$, with "three vertical and four horizontal" as the skeleton, a trunk line through the ports, cities and counties, and extension to the island's 318 towns and tourist attractions, around the island highway Has been completed and opened to traffic, in addition, the railway has been completed Hainan Island Express Railway (Hainan West Ring Express Railway, Hainan East Central Express Railway) and the Guangdong-Hainan Railway Hainan West Link (including eight regional and Shilu branch line).

Secondly, in improving traffic construction at the same time to enrich the "line" of tourism functions, good traffic along the landscaping, the cable will be built into a beautiful landscape with people on the road will be able to get a pleasant experience to build the journey Of the landscape. Namely, Haikou and Sanya are the two endpoints. Hainan's tourism itinerary is divided into three lines, one is the coastal tourism landscape of the east coast, the other is the primitive jungle scenery line of the west coast. These tourist routes rely on the formation of various tourist spots, the shape of the distribution of linear shape in the tourism space, with its axis and foundation, focusing on the development of tourism activities in more areas of the tourist line, for other tourist lines will play a leading role, Tourism line development, so that the allocation of resources has been a reasonable allocation, will promote the expansion of space and tourism development process.

\subsection{Co-Ordinate the layout and multi-regulation}

In the "surface" of the building, to "soft and hard", one is to increase tourism infrastructure, tourism information services and consulting services network coverage and other hard environment construction. First of all, it is necessary to improve the infrastructure construction and we must strengthen the road network, optical network, power grid, gas network, water network construction of the five networks. Second, in the face of the advent of the FIT, online travel has been rapid development, and promotes China's tourism industry into the "big tourism data" era. Therefore, to strengthen the application of integrated Hainan cloud tourism platform, establish and improve the Hainan intelligent tourism management system, the implementation of wireless broadband services in important tourist areas, establish and improve the wisdom of tourism in Hainan public service system, promote "tourism + Internet" strategic cooperation, build Hainan wisdom tourism Marketing system, vigorously develop new forms of online travel, support to encourage the "tourism + Internet" pilot demonstration 
and the positive development of tourism products, e-commerce platform and accelerate the integration of development and standardization of construction and other measures and means have become the basis for the development of global tourism.

Second, it is necessary to optimize the soft environment for tourism development, improve the quality and level of tourism services, and comprehensively enhance the civilized quality of the citizens of the province, and continue to promote civilized action to promote civilized literacy. First of all, should strengthen education and training and human resources management, improve the quality of employees. Tourism practitioners - whether grass-roots service personnel or tourism management or tourism development personnel, must have a high cultural and artistic taste. Secondly, it needs to train tourism employees a good attitude. Tourists have to be respected needs, the attitude of tourist service is the focus of attention of tourists, so the attitude is correct, directly determines the quality of tourism service evaluation of tourists.

\section{Conclusion}

By analyzing the advantage, disadvantage, opportunity and threat of the whole tourism development in Hainan Province by using the SWOT situation analysis method, we can draw a clear and concrete direction and development countermeasure, in order to provide useful inspiration for the development of a scientific and effective model of global tourism development in Hainan Province. 